\title{
The Effect of Promotion Mix on Consumer Decisions using Grab-Food in Palembang
}

\author{
Rizana Oktari, Zakaria Wahab, Marlina Widiyanti
}

\begin{abstract}
This study is entitled The Effect of Promotion Mix on Consumer Decisions in Using Grab-Food in Palembang. The purpose of this study was to determine the effect of the promotional mix on consumer decisions in using Grab-Food in Palembang. The results showed that advertising variables (X1), sales promotion (X2), publicity (X3), direct marketing (X4) had a significant effect on consumer decisions in using Grab-Food in Palembang ( $Y$ ). This is evidenced by the calculation of the $F$ test, obtained an F-count greater than the F-table of 23,956. with Adjusted $R$ square value of 711,440. The promotion mix consisting of advertising, sales promotion, publicity, and direct marketing together has a significant effect on consumer decisions.

Keywords: Promotion mix, Consumer decisions.
\end{abstract}

\section{INTRODUCTION}

Since information technology and the development of the online world has advanced rapidly. The internet is accessible to all people in the world, which makes it easy to find and find information. In a country's economy, information technology is felt to have a very important role. With the advancement of information technology will increase the productivity capabilities of the industrial world such as creative industries that are based on information technology. Then in accordance with current developments that are all-round using mobile devices, all trading activities can be done easily. As a result of lifestyle changes in Indonesian society has an influence on food consumption patterns. Social activities and social life in the community make them usually want something practical in terms of meeting food needs. Restaurant and UMKM culinary industry is a solution in terms of meeting food needs for consumers who do not want to bother in preparing food. One of the innovations that must be given by food industry business actors is the ease in the process of sending and serving food to consumers.

Along with the needs of culinary business people who need convenience in the food delivery process and also consumers who have limited time in meeting food needs, food delivery services are here to provide solutions. Food delivery services lately are increasingly in demand. Companies engaged in the business model field usually

Revised Manuscript Received on January 03, 2020.

* Correspondence Author

Rizana Oktari*, Student Magister Management, Economic Faculty of Sriwijaya Univeristy , Palembang , Indonesia. Email: rizanaokt@gmail.com

Zakaria Wahab, Lecturer of Magister management Economic Faculy, Sriwijaya University, Palembang Indonesia

Marlina Widiyanti, Lecturer of Magister management Economic Faculy, Sriwijaya University, Palembang Indonesia

(c) The Authors. Published by Blue Eyes Intelligence Engineering and Sciences Publication (BEIESP). This is an open access article under the CC BY-NC-ND license (http://creativecommons.org/licenses/by-nc-nd/4.0/) collaborate with restaurants in various places so they can order food through their website or application. Then food that consumers have ordered will be delivered by courier service. Services like this are increasingly liked by the community because people do not need to bother anymore to go to the location and queue up. So that people only have to wait at home and food arrives at home. The number of people who have limitations in meeting their daily food needs in Palembang is an opportunity for Grab Indonesia. In addition to providing online transportation services, on May 22016 Grab also provided food delivery services through the Grab-Food feature in the Grab mobile application.

\section{LITERATURE REVIEW}

\section{A. Definition of Advertising}

All forms of non-personal presentation and promotion of ideas, goods or services carried out by certain sponsor companies. Media commonly used in advertising are electronic media, print and electronic. According to Kotler \& Kevin (2009), advertising as a form of paid non-personal presentation and promotion regarding ideas, goods or services by a known sponsor. While Keegan (2013) states that advertising can be defined as a sponsored message, which is placed in the mass media for a certain fee.

\section{B. Definition of Sales Promotion}

Short-term incentives to encourage the desire to try or buy a product or service. According to (Wahjono, 2010), sales promotions are promotional activities carried out by selling directly to customers. Sales promotion activities can be in the form of giving discounts, giving product shopping vouchers, giving direct prizes, sample (sample) products or by contest activities. Meanwhile, according to Graham (2011), sales promotion is a marketing activity that stimulates consumer purchases and increases the effectiveness and cooperation of retailers and intermediaries.

\section{Definition of Publicity}

Various programs to promote and / or protect the image of the company or each of its products. According to Wahjono (2010), publicity is an activity in order to introduce to the public with media that are known to be non-commercial. Public relations performs a number of key functions according to Kotler \& Armstrong (2012).

Published By:

Blue Eyes Intelligence Engineering

\& Sciences Publication

DOI:10.35940/ijmh.E0511.014520

Journal Website: www.ijmh.org 


\section{Definition of Direct Marketing (database marketing)}

Direct marketing relationships with targeted consumers with the aim of obtaining immediate responses and fostering long-term relationships with consumers. The form of promotion used is the use of applications to communicate directly with or solicit responses or dialog from certain customers.

\section{E. Definition of Purchasing Decisions}

Based on the purpose of the purchase, consumers can be classified into two groups, namely end consumers (individuals) and organizational consumers (industrial consumers, intermediary consumers, and business consumers). Requirements that must be met by a company in order to be successful in competition are trying to achieve the goal of creating and retaining customers because the survival of the company as an organization that seeks to meet the wants and needs of consumers is very dependent on consumer behavior

\section{Conceptual Framework}

Conceptual framework is a scientific explanation of prepositions between links or relationships between research variables. Linkages or relationships between these variables are important raised as a basis for formulating research (Juliandi \& Irfan, 2013)

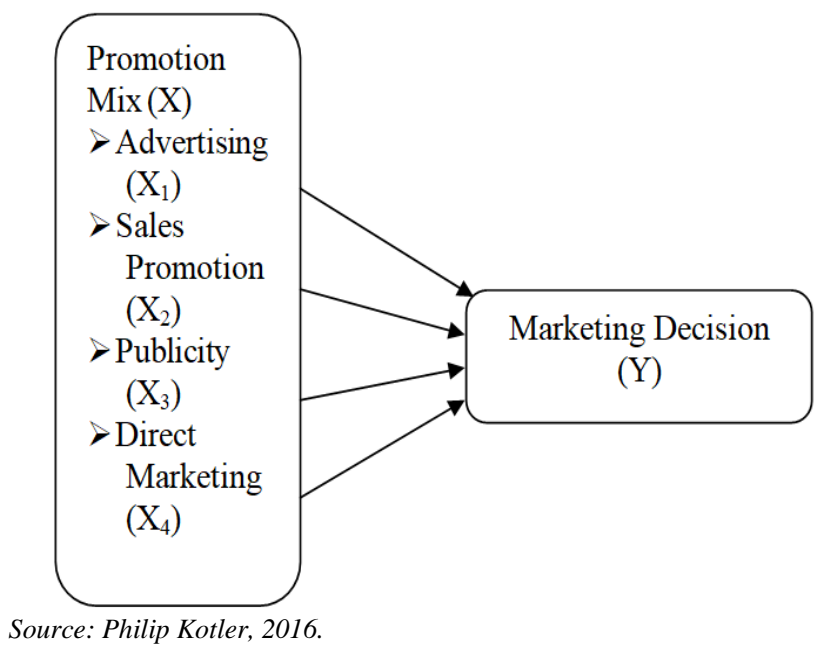

Figure 1. conceptual framework

Research Hypothesis

H1: Advertising has a positive effect on consumers' decisions to use Grab Food in Palembang.

H2: Sales Promotion is very influential on consumer decisions in using Grab Food in Palembang

H3: Publicity influences the consumer's decision to use Grab Food in Palembang

H4: Direct Marketing is not very influential on consumer decisions in using Grab Food in Palembang.

\section{RESEARCH MEHODS}

\section{A. Method}

Scope of Research The effect of promotion mix on consumer decisions in using Grab-Food in Palembang. Consumers who want to be investigated are consumers who have used Grab-Food in Palembang.

\section{B. Types of research}

The type of data collected in this study was divided into two namely: Primary Data, namely data obtained from the results of a questionnaire distributed to consumers using Grab Food in Palembang.

Secondary data, i.e. data obtained from documents, research reports and internet websites that support primary data.

\section{Population and Sample}

The population in this study were all consumers who use Grab-Food in Palembang (Students of the Faculty of Economics, Sriwijaya University).

This research was conducted for approximately 4 months. Conducted from early August to December 2019. Samples are part of the number of characteristics possessed by the population. The sample of this research is consumers who use Grab Food in Palembang.

\section{Method of collecting data}

In this study, data collection was carried out using the technique as Observation, which is directly observing phenomena related to the promotion mix (advertising, sales promotion, publicity, and personal sales) and consumer decisions using Grab Food in Palembang to supplement primary data obtained through questionnaires. Questionnaire, which is a method of data collection which is carried out by giving a list of statements or questions (questionnaire) to the respondent with the answer choice guide. Guide to the choice of answers to the questionnaire in this study using statements or closed questions related to the marketing mix and consumer decisions using Grab Food in Palembang.

\section{E. Data analysis technique}

Data Analysis Techniques used in this research are to use quantitative descriptive analysis to provide an overview and answer the problem formulation. The data analysis technique used to answer the problems raised in this study is multiple linear regression analysis.

Test Research Instrument

\section{F. Validity test}

Validity test is done to find out whether the measuring instrument that has been made can be used to measure what is being measured precisely. The type of validity used is construct validity. To test the validity, Pearson's product moment correlation technique will be used which is compared with $r$ tables (Sugiyono, 2012). If r-count> r-table then the instrument is declared valid and vice versa.

\section{G. Reliability Test}

Reliability means the level of reliability of the results of a measurement. Measurements that have high reliability, namely measurements that are able to provide reliable measurement results (reliable). Reliability is one of the main characteristics or characteristics of good measurement instruments. Sometimes reliability is also referred to as trustworthiness, reliability, constancy, consistency, stability, etc., but the main idea in the concept of reliability is the

Published By:

Blue Eyes Intelligence Engineering

\& Sciences Publication 
extent to which the results of a measurement can be trusted, meaning the extent to which the measurement results are free from measurement errors.

\section{Research Data Analysis}

Multiple linear regression is a tool for forecasting the value of the influence of two or more independent variables on one dependent variable to prove the presence or absence of a function relationship or the causal relationship of the independent variable to the dependent variable. The multiple linear regression equation is formulated as follows:

Consumer Decisions $=\alpha+\beta 1$ Advertising $+\beta 2$ Sales Promotion $+\beta 3$ Publicity $+\beta 4$ Direct Marketing $+\mathrm{e}$

$$
\begin{aligned}
& Y=\text { Purchase Decision } \\
& X 1=\text { Advertising } \\
& \text { X2 = Sales Promotion } \\
& \text { X3 = Publicity } \\
& \text { X4 = Direct Marketing } \\
& \alpha=\text { Constant } \\
& \beta 1, \beta 2, \beta=\text { Regression Coefficient } \\
& \text { ei }=\text { error }
\end{aligned}
$$

\section{H. Classic assumption test}

In the equation of the multiple linear regression model, several basic assumptions are known to assess a model with a view to knowing whether the specified regression equation is a model that can produce unusual etimation. The assumption test can be described as follows.

\section{Normality test}

Normality test aims to test whether in the regression model, confounding or residual variables have a normal distribution. The decision making is if the Kolmogorov Smirnov test value is not significant (smaller than 2), then the data is normally distributed, or if the probability is greater than 0.05 then the data is normally distributed (Winarno, 2015)

\section{J. Multicollinearity Test}

Multicollinearity test is performed to determine whether there is a significant relationship between independent variables. Detection of multicollinearity is performed by regression of an independent variable to other independent variables in the model. To test the presence or absence of multicollinearity.

To test the presence or absence of multicollinearity can be seen from the value of R-Square, F-count and standard error. $\mathrm{H} 0$ : if the R-square value $<\mathrm{R}$-square value of the main model shows that there is no Multicollinearity problem. H1: If the $\mathrm{R}$-square value $>\mathrm{R}$-square value of the main model shows that there are 52 multicollinity problems

\section{K. Heteroscedasticity Test}

Heteroscedasticity test is one way to detect the presence or absence of heterocedasticity problems using the White Heterokedasticity Test. H0: if the statistical chi-square obs value <chi-square table value with a certain degree of confidence $(\alpha)$ indicates the absence of heterocedasticity $\mathrm{H} 1$ : If the statistical chi-square obs value $>$ the chi-square table value with a certain degree of trust $(\alpha)$ then there is heteroscedasticity.

\section{Autocorrelation Test}

Autocorrelation Test is an Aotukorrelation test conducted one of them with the Breusch Godfrey Serial Correlation LM Test. H0: If the statistical chi-square obs value <chi square table value with a certain degree of confidence $(\alpha)$ then there is no autocorrelation. H1: If the statistical chi-square obs value $>$ chi square table value with a certain degree of confidence $(\alpha)$ then there is Autocorrelation.

\section{Hypothesis testing}

To obtain the best regression model or BLUE (Best Linear Unlock Estimator) several criteria must be met, among others, by conducting the F Test and the t Test.

1) The hypotheses in this test are:

Ho: $\beta=0$. That is, the free variable has no effect on the dependent variable.

Ha: $\beta \neq 0$. That is, the free variable affects the dependent variable.

2) Test statistics to be used are the F-Test of the F-Snedecor distribution through the ANOVA list (analysis of variance). 3) The test criteria are: accept Ho, if F-count is smaller than F-table (F-count $<$ F1- $\alpha$; k: n-k-1).

reject Ho, if F-count is greater than F-table (F-count $>$ F1- $\alpha$; $\mathrm{k}: \mathrm{n}-\mathrm{k}-1)$.

\section{N. T test: Partial Test}

The $\mathrm{t}$ test basically shows whether the independent variables entered in the model have an influence on the dependent variable individually (partial).

1) The hypotheses in this test are:

Ho: bi $\leq 0$. This means that there is no influence of the $\mathrm{i}$-th variable on the dependent variable.

Ha: bi $>0$. This means that there is an influence of the $\mathrm{i} i$ variable on the dependent variable.

2) Test statistics that will be used are t-test with the formula:

The test criterion is to reject Ho, if p-value <a or t-count> t-table, where t-table $=\mathrm{t} 1-\mathrm{a} / 2$; $\mathrm{n}-\mathrm{k}-1$. If Ho is rejected, it means that there is a significant influence between the $i$ variable on the dependent variable.

\section{O. Coefficient of Determination (R2)}

To find out how far the independent variable can explain the dependent variable, it is necessary to know the coefficient of determination or determination of the $\mathrm{R}^{2}$ value ranges from $0-1$, the closer to 1 the $R^{2}$ value means the greater the independent variable $(\mathrm{X})$ is able to explain the dependent variable $(\mathrm{Y})$. Analysis of the value of $\mathrm{R}$-Square or $\left(\mathrm{R}^{2}\right)$ is used to determine the extent to which the independent variable $(\mathrm{X})$ can explain the relationship of changes in the dependent variable (Y). The properties of R-Square are strongly influenced by the number of independent variables, where the more independent variables the greater the value of R-Square.

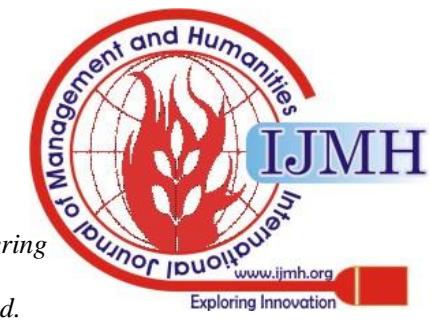




\section{RESULT AND DISCUSSION}

\section{A. Research Instrument Test Results}

The results of the validity and reliability test using 20 people as respondents with the help of the SPSS (Statistical Product and Service Solution) Version 20.0 program have been carried out for each Independent variable consisting of 4 items of Advertising variable (X1), 4 items of Sales Promotion variable (X2), 4 Publicity variable items (X3), 4 Direct Marketing variable items (X4) and Dependent variables which consist of 4 Consumer Decision variable items (Y).

Table I. Validity Test Results for Research Instrument Variables

\begin{tabular}{|c|c|c|c|c|}
\hline Variabel & Butir & $\begin{array}{c}\text { r-hitun } \\
\text { g }\end{array}$ & r-tabel & $\begin{array}{c}\text { Keterang } \\
\text { an }\end{array}$ \\
\hline \multirow{4}{*}{$\begin{array}{l}\text { Advertising } \\
\left(\mathrm{X}_{1}\right)\end{array}$} & 1 & 0,510 & 0,361 & Valid \\
\hline & 2 & 0,522 & 0,361 & Valid \\
\hline & 3 & 0,492 & 0,361 & Valid \\
\hline & 4 & 0,487 & 0,361 & Valid \\
\hline \multirow{4}{*}{$\begin{array}{c}\text { Sales } \\
\text { Promotion } \\
\left(\mathrm{X}_{2}\right)\end{array}$} & 1 & 0,664 & 0,361 & Valid \\
\hline & 2 & 0,634 & 0,361 & Valid \\
\hline & 3 & 0,596 & 0,361 & Valid \\
\hline & 4 & 0,505 & 0,361 & Valid \\
\hline \multirow{4}{*}{$\begin{array}{l}\text { Publicity } \\
\left(\mathrm{X}_{3}\right)\end{array}$} & 1 & 0,599 & 0,361 & Valid \\
\hline & 2 & 0,500 & 0,361 & Valid \\
\hline & 3 & 0,437 & 0,361 & Valid \\
\hline & 4 & 0,491 & 0,361 & Valid \\
\hline \multirow{4}{*}{$\begin{array}{c}\text { Direct } \\
\text { Marketing } \\
\left(\mathrm{X}_{4}\right)\end{array}$} & 1 & 0,686 & 0,361 & Valid \\
\hline & 2 & 0,445 & 0,361 & Valid \\
\hline & 3 & 0,414 & 0,361 & Valid \\
\hline & 4 & 0,455 & 0,361 & Valid \\
\hline \multirow{4}{*}{$\begin{array}{l}\text { Consumer } \\
\text { Decision } \\
(\mathrm{Y})\end{array}$} & 1 & 0,687 & 0,361 & Valid \\
\hline & 2 & 0,664 & 0,361 & Valid \\
\hline & 3 & 0,565 & 0,361 & Valid \\
\hline & 4 & 0,552 & 0,361 & Valid \\
\hline
\end{tabular}

Source: Primary data processed, 2019.Appendix 2 - 6 (Corrected Item-Total Correlation) 0.

Based on the test results show that all items of the instrument statement advertising variables (X1), sales promotion (X2), publicity (X3), direct marketing (X4), and consumer decision variables $(\mathrm{Y})$ show the calculated $\mathrm{r}$ value is greater than the value of $\mathrm{r}$ - table (r-count> 0.361 ), thus all instruments are declared valid at $5 \%$ significance level. These results indicate that all items of statement items used as instruments of the research variables are declared Valid and meet the requirements to be used as research measurement tools.

\section{Reliability Test}

Reliability test is used to find out whether the measuring device has reliability in measuring a dimension. In the sense that if the measurements are made repeatedly will give the same results in every measurement. In this case if the value of the Reliability Coefficient (Alpha) is greater than $0.6(\alpha>$ 0.6 ), then the measured variables and items can be trusted or relied upon.
Table II. Reliability Test Results

\begin{tabular}{|l|l|c|c|c|}
\hline No & Variabel & $\begin{array}{l}\text { N Of } \\
\text { Case } \\
\text { s }\end{array}$ & $\begin{array}{l}\text { N Of } \\
\text { Item }\end{array}$ & $\begin{array}{l}\text { Hasil Uji } \\
\text { Reliabilit } \\
\text { as }\end{array}$ \\
\hline 1 & Advertisng $\left(\mathrm{X}_{1}\right)$ & 30 & 4 & 0,707 \\
\hline 2 & $\begin{array}{l}\text { Sales Promotion } \\
\left(\mathrm{X}_{2}\right)\end{array}$ & 30 & 4 & 0,788 \\
\hline 3 & Publicity $\left(\mathrm{X}_{3}\right)$ & 30 & 4 & 0,715 \\
\hline 4 & $\begin{array}{l}\text { Direct } \\
\text { Marketing }\left(\mathrm{X}_{4}\right)\end{array}$ & 30 & 4 & 0,707 \\
\hline 5 & $\begin{array}{l}\text { Consumer } \\
\text { Decision (Y) }\end{array}$ & 30 & 4 & 0,802 \\
\hline
\end{tabular}

Source: Primary data processed, 2019. Appendix 2 - 6 (Reliability Statistics - Cronbach's Alpha)

From the reliability test results in the above table, both the reliability test results of advertising variables, sales promotion, publicity, and direct marketing, as well as the reliability test results for consumer decision variables, all of which show the reliability data with Alpha Cronbach's overall value above 0.60 . This result means that the measuring instrument used is said to be Reliable and meets the requirements and is reliable.

\section{Classic assumption test}

The classic assumption test includes the normality test, multicollinearity test, hederoskedasticity test, and auto correlation test. Based on calculations that have been carried out as follows.

\section{Normality test}

Normality test is carried out whether the residuals follow the normal distribution or not. In this study the normality test was carried out with the Kolmogorov-Smirnov test with the following results.

Table III. Kolmogorov-Smirnov Test Results One-Sample Kolmogorov-Smirnov Test

\begin{tabular}{|l|l|r|}
\hline \multicolumn{2}{|l|}{} & $\begin{array}{r}\text { Unstandardi } \\
\text { zed Residual }\end{array}$ \\
\hline N & 100 \\
\hline Normal Parameters \\
& Mean & .0000000 \\
\cline { 2 - 3 } & Std. Deviation & 2.07759262 \\
\hline $\begin{array}{l}\text { Most Extreme } \\
\text { Differences }\end{array}$ & Absolute & .096 \\
\cline { 2 - 3 } & Positive & .096 \\
\cline { 2 - 3 } & Negative & -.088 \\
\hline Test Statistic & & .096 \\
\hline Asymp. Sig. (2-tailed) & .200 \\
\hline
\end{tabular}

Published By:

Blue Eyes Intelligence Engineering \& Sciences Publication 
Based on the results of the above analysis it can be seen that the asymptotic significance produced is 0.200 which is greater than 0.05 . So it can be concluded that residuals are normally distributed and normality assumptions are met.

\section{Multicollinearity Test}

Multicollinearity testing aims to determine whether there is a correlation between independent variables, namely by calculating the value of Variance Inflation Factor (VIF). Data is said to contain multicollinearity if the VIF value is more than 10. Following is the calculation of the VIF value for all independent variables in the study.

Table IV. Multicollinearity Test Results

\begin{tabular}{|c|c|c|c|}
\hline \multirow{2}{*}{\multicolumn{2}{|c|}{ Model }} & \multicolumn{2}{c|}{ Collinearity Statistics } \\
\cline { 3 - 4 } \multicolumn{1}{|c|}{1} & (Constant) & Tolerance & VIF \\
\cline { 2 - 4 } & advertising & .434 & 2.302 \\
\cline { 2 - 4 } & promotion & .373 & 2.679 \\
\cline { 2 - 4 } & Publicity & .400 & 2.497 \\
\cline { 2 - 4 } & marketing & .362 & 2.761 \\
\hline
\end{tabular}

Based on the results of the above analysis it can be seen that the VIF values for advertising, sales promotion, publicity and direct marketing variables are more than 10 , it can be concluded that there is no correlation between the independent variables in the data so that the multicollinearity assumptions are met.

\section{Heteroscedasticity Test}

To detect the existence of heterokedasticity problems can be done by looking at the output of SPSS on scatterplot charts. Heterokedastisitas test results are illustrated in the following graph.

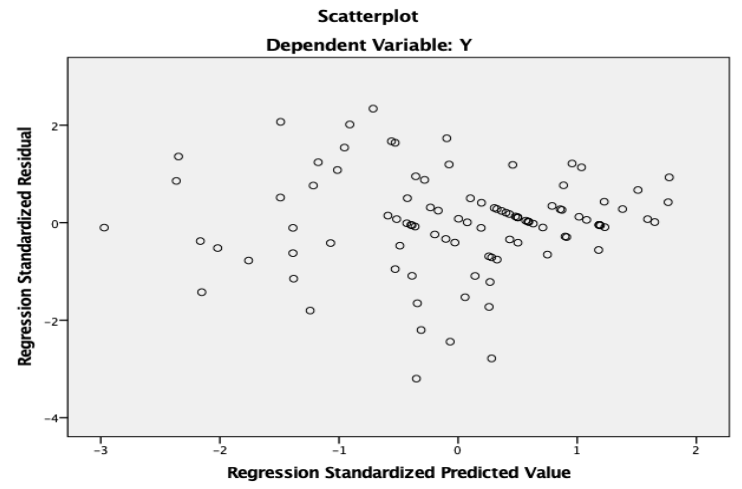

Based on the scatterplot output above, that point spreads and does not form a certain pattern. This is not a problem of heterokedasticity in research.

\section{Autocorrelation Test}

Table V. Autocorrelation Test Result

\begin{tabular}{|c|c|c|}
\hline $\begin{array}{c}\text { Lower Limit } \\
(D L)\end{array}$ & $\begin{array}{c}\text { Statistical Value } \\
\text { Calculate (DW) }\end{array}$ & $\begin{array}{c}\text { Upper Limit } \\
(D U)\end{array}$ \\
\hline 1.5922 & 1,801 & 1,7582 \\
\hline
\end{tabular}

The results of the analysis can be seen that the statistical value of DW $=1.801$ is more than the Durbin - Watson limit of 1.7582 So that it can be stated that there is no positive autocorrelation. For the 4-DW $=4-1,801=2,199$ count results from the Durbin - Watson table limit of 1.7582, it can be stated that there is no negative autrocorrelation. Based on the results, it can be concluded that the assumption of autocorrelation is fulfilled.

\section{Research Data Analysis Results}

Table VI. Model Unstandardized coefficients Standardized coefficients

\begin{tabular}{|l|c|c|c|c|}
\hline \multirow{2}{*}{ Model } & \multicolumn{2}{|c|}{$\begin{array}{c}\text { Unstandardized } \\
\text { coefficients }\end{array}$} & $\begin{array}{c}\text { Standardize } \\
\text { d coefficients }\end{array}$ & \multirow{2}{*}{ Sig. } \\
\cline { 2 - 4 } & $\mathbf{B}$ & $\begin{array}{c}\text { Std. } \\
\text { error }\end{array}$ & Beta & 0,031 \\
\hline (Constant) & 2,646 & 1,210 & & 0,038 \\
\hline $\begin{array}{l}\text { Adveritising } \\
\left(\mathrm{X}_{1}\right)\end{array}$ & 0,180 & 0,085 & 0,187 & 0,045 \\
\hline $\begin{array}{l}\text { Sales } \\
\text { Promotion } \\
\left(\mathrm{X}_{2}\right)\end{array}$ & 0,165 & 0,081 & 0,226 & 0,048 \\
\hline $\begin{array}{l}\text { Publicity }\left(\mathrm{X}_{3}\right) \\
\begin{array}{l}\text { Punn } \\
\text { Direct }\end{array}\end{array}$ & 0,197 & 0,098 & 0,212 & 0,037 \\
$\begin{array}{l}\text { Marketing } \\
\left(\mathrm{X}_{4}\right)\end{array}$ & 0,205 & 0,097 & 0,250 & \\
\hline
\end{tabular}

source: Primary data processed 2019.

\section{Coefficient of Determination}

Based on the analysis of the coefficients with the Summary Model in table 4.9 above, it is known that the value of the multiple correlation coefficient $(\mathrm{R})=0.709$ and the coefficient of determination (R-Square / R2) is 0.502. Thus it can be stated that $50.2 \%$ of the variation in consumer decisions can be explained by the promotion mix factor consisting of advertising (X1), sales promotion (X2), publicity (X3), and direct marketing (X4) together through the formula Regression equation: $\mathrm{Y}=2.646+0.180 \mathrm{X} 1+$ $0.165 \mathrm{X} 2+0.197 \mathrm{X} 3+0.205 \mathrm{X} 4$. These results indicate that the promotion mix factors consisting of advertising, sales promotion, publicity, and direct marketing together have a positive influence on consumer decisions by $50.2 \%$, while the remaining $49.8 \%$ is influenced by other factors beyond the study.

\section{Hypothesis testing}

Hypothesis testing or parameter significance testing is carried out simultaneously with the F test and partially the $t$ test. The following hypotheses test results simultaneously and partially. To determine the formula for multiple linear regression equations, the influence of the promotion mix variable (advertising, sales promotion, publicity, and direct marketing) on consumer decisions in using Grab-Food in Palembang needs to be done regression coefficient analysis. The results are as follows: multiple regression constants; 2,646, advertising variable regression coefficient (X1), 0,180 , sales promotion variable regression coefficient $(\mathrm{X} 2)$, 0,165, publicity variable regression coefficient (X3), 0,197, and direct marketing variable regression coefficient (X4), 0,205 .

Published By:

Blue Eyes Intelligence Engineering \& Sciences Publication 


\section{Test F (ANOVA)}

$\mathrm{F}$ test analysis (ANOVA) was conducted to test the significance of the multiple linear regression equation and the significance of the influence of the promotion mix factor consisting of advertising (X1), sales promotion (X2), publicity (X3), and direct marketing (X4) together against consumer decision $(\mathrm{Y})$.

Table VII. F- Test Analysis: Promotion Mix Against Consumer Decisions

\begin{tabular}{|c|c|c|c|c|c|}
\hline Model & $\begin{array}{c}\text { Sum of } \\
\text { squares }\end{array}$ & df & $\begin{array}{c}\text { Mean } \\
\text { square }\end{array}$ & F & Sig. \\
\hline Regresi & 357.255 & 4 & 89.314 & $\begin{array}{c}23.95 \\
6\end{array}$ & 0.000 \\
\hline $\begin{array}{c}\text { Residu } \\
\text { al }\end{array}$ & 354.185 & 95 & 3.728 & & \\
\hline Total & 711.440 & 99 & & & \\
\hline
\end{tabular}

Source: Primary Data Processed, 2019.

F-calculate the effect of $\mathrm{X} 1, \mathrm{X} 2, \mathrm{X} 3$ and $\mathrm{X} 4$ on $\mathrm{Y}$ with $\mathrm{N}$ as many as 99 degrees of freedom (df) 4 , the F-calculated value is 23.955. Based on the data above, the F-calculated price of 23.956 is greater than the F-table price (df $4: 95$ ) at a $95 \%$ confidence level of 2,467 (23,956>2,467), with a significant probability value of $\mathrm{F}$ (Sig.) $=0,000$ more smaller than Alpha 0.05 (Sig. F $0,000<\alpha 0.05$ ). Thus it can be concluded that; 1 ) the direction coefficient of multiple linear regression means, and 2) promotion mix factors consisting of advertising, sales promotion, publicity, and direct marketing together have a significant effect on consumer decisions.

\section{T test}

$\mathrm{T}$ test analysis was conducted to see how the influence of the promotional mix factors consisting of advertising, sales promotion, publicity, and personal selling individually (partial) to consumer decisions by looking at the t-count value or the value of the significant probability level $t$ (Sig.).

Table VIII. T-test analysis (p-value)

\begin{tabular}{|c|l|c|c|c|c|}
\hline No & Parameter & Beta & Sig. & $\boldsymbol{a ~ 0 , 0 5}$ & Informatio \\
\hline 1 & Intercept $(\mathrm{a})$ & & 0,031 & $<0,05$ & Significant \\
\hline 2 & $\begin{array}{l}\text { Advertising } \\
\left(\mathrm{X}_{1}\right)\end{array}$ & 0,187 & 0,038 & $<0,05$ & Significant \\
\hline 3 & $\begin{array}{l}\text { Sales } \\
\text { Promotion }\left(\mathrm{X}_{2}\right)\end{array}$ & 0,226 & 0,045 & $<0,05$ & Significant \\
\hline 4 & Publicity $\left(\mathrm{X}_{3}\right)$ & 0,212 & 0,048 & $<0,05$ & Significant \\
\hline 5 & $\begin{array}{l}\text { Direct } \\
\text { Marketing }\left(\mathrm{X}_{4}\right)\end{array}$ & 0,250 & 0,037 & $<0,05$ & Significant \\
\hline
\end{tabular}

Source: Primary data processed, 2019.

Based on the above table, the results of the $t$ test analysis of the parameters can be described as follows:

a. Parameter a (intercept) has a significant influence on consumer decisions, because the value of t-count 2.186 is greater than t-table 1.984 (t-count 2.186> t-table 1.984), with a significant probability level value t (Sig.) 0.031 is smaller than Alpha 0.05 (Sig. $0.031<\alpha$ 0.05). This means that with the promotion mix variable consisting of advertising, sales promotion, publicity, and direct marketing has a significant influence on consumer decisions.

b. Parameter of advertising factor (X1) has a beta value of 0.187 with a t-count value of 2.106 greater than t-table 1.984 (t-count 2.106> t-table 1.984), with a significant probability level value t (Sig.) of 0.038 less than Alpha 0.05 (Sig. 0.038 $<\alpha 0.05$ ). This means that partially the advertising factor which includes all forms of non-personal presentation and promotion of ideas, goods or services carried out by Grab-Food has a significant influence on consumer decisions by $18.7 \%$.

c. Parameter of sales promotion factor (X2) has a beta value of 0.226 with a $\mathrm{t}$-count value of 2.034 greater than t-table 1.984 (t-count 2.034> t-table 1.984), with a significant probability level value $\mathrm{t}$ (Sig.) by 0.045 smaller than Alpha 0.05 (Sig. $0.045<\alpha 0.05$ ). This means that partially sales promotion factors which include various short-term incentives to encourage the desire to try or buy Grab-Food products have a significant influence on consumer decisions by $22.6 \%$.

d. Parameter of publicity factor (X3) has a beta value of 0.212 with a t-count value of 2.007 greater than t-table 1.984 (t-count 2.007> t-table 1.984), with a significant probability level value t (Sig.) of 0.048 less than Alpha 0.05 (Sig. 0.048 $<\alpha 0.05$ ). This means that partially the publicity factor which includes various programs to promote and / or protect the image of Grab-Food or each of its products has a significant influence on consumer decisions by $21.2 \%$.

e. Parameter of direct marketing factor (X4) has a beta value of 0.250 with a t-count value of 2.121 greater than t-table 1.984 (t-count 2.121> t-table 1.984), with a significant probability level value $\mathrm{t}$ (Sig.) by 0.037 smaller than Alpha 0.05 (Sig. $0.037<\alpha 0.05$ ). This means that partially the direct marketing factor which includes direct interaction with potential Grab-Food consumers, in order to make presentations, answer questions and receive orders has a significant influence on consumer decisions by $25.0 \%$.

\section{RESEARCH RESULTS FOR EACH VARIABLE}

\section{A. Effects of Advertising on Consumer Decisions}

Based on the results of the $t$ test in the advertising factor regression (X1) which has a Beta value of 0.187 with a significant level of probability value $t$ (Sig.) 0.038 smaller than Alpha $(\alpha) 0.05$, this result can be interpreted that the advertising factor which includes all forms non-personal presentation and promotion of ideas, goods or services carried out by Grab-Food has an influence on consumer decisions in using Grab-Food in Palembang by $18.7 \%$. Based on the results of the significant test, the parameters of the advertising factor (X1) have a beta value of 0.187 with a $\mathrm{t}$-count value of 2.106 greater than $\mathrm{t}$-table 1.984 (t-count 2.106> t-table 1.984), with a significant probability level value $t$ (t-table) Sig.) Of 0.038 less than Alpha 0.05 (Sig. $0.038<\alpha 0.05$ ). This means that partially the advertising factor which includes all forms of non-personal presentation and promotion of ideas, goods or services carried out by Grab-Food has a significant influence on consumer decisions by $18.7 \%$.

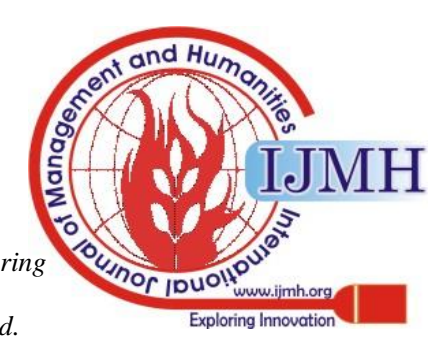




\section{B. The Effect of Sales Promotion on Consumer Decisions}

Based on the results of the test in the sales promotion factor regression (X2) which has a Beta value of 0.226 with a significant level of probability value t (Sig.) 0.045 smaller than Alpha $(\alpha) 0.05$, this can be interpreted that sales promotions that include various Short-term incentives to encourage the desire to try or buy Grab-Food products have an influence on consumer decisions in using Grab-Food in Palembang by $22.6 \%$. Based on significant test results, the parameters of the sales promotion factor (X2) have a beta value of 0.226 with a t-test value of 2.034 greater than t-table 1.984 (t-count 2.034> t-table 1.984), with a significant probability level value $t$ ( Sig.) Of 0.045 smaller than Alpha 0.05 (Sig. $0.045<\alpha 0.05$ ). This means that partially sales promotion factors which include various short-term incentives to encourage the desire to try or buy Grab-Food products have a significant influence on consumer decisions by $22.6 \%$.

\section{Publicity of Consumer Decisions} regression (X3) which has a Beta value of 0.212 with a significant level of probability value t (Sig.) 0.048 smaller than Alpha $(\alpha) 0.05$, this result can be interpreted that publicity which includes various programs for promoting and / or protecting the image of Grab-Food or each of its products has an influence on consumer decisions in using Grab-Food in Palembang by $21.2 \%$. Based on the significant test results, the parameter of publicity factor (X3) has a beta value of 0.212 with a t-count value of 2.007 greater than t-table 1.984 (t-count 2.007> t-table 1.984), with a significant probability level value $t$ (Sig .) equal to 0.048 smaller than Alpha 0.05 (Sig. $0.048<\alpha 0.05$ ). This means that partially the publicity factor which includes various programs to promote and / or protect the image of Grab-Food or each of its products has a significant influence on consumer decisions by $21.2 \%$.

\section{Publicity of Consumer Decisions}

Based on the results of the t test in the publicity factor regression (X3) which has a Beta value of 0.212 with a significant level of probability value $t$ (Sig.) 0.048 smaller than Alpha $(\alpha) 0.05$, this result can be interpreted that publicity which includes various programs for promoting and / or protecting the image of Grab-Food or each of its products has an influence on consumer decisions in using Grab-Food in Palembang by $21.2 \%$. Based on the significant test results, the parameter of publicity factor (X3) has a beta value of 0.212 with a t-count value of 2.007 greater than t-table 1.984 (t-count 2.007> t-table 1.984), with a significant probability level value $t$ (Sig .) equal to 0.048 smaller than Alpha 0.05 (Sig. $0.048<\alpha 0.05$ ). This means that partially the publicity factor which includes various programs to promote and / or protect the image of Grab-Food or each of its products has a significant influence on consumer decisions by $21.2 \%$.

E. Direct Marketing of Consumer Decisions

Based on the results of the test in regression, it is known that direct marketing (X4) has a beta value of 0.250 with a significant probability value of t (Sig.) 0.037 smaller than Alpha $(\alpha) 0.05$, this result gives the sense that direct marketing which includes direct interaction with potential Grab-Food consumers, in order to answer questions and receive orders has the most dominant influence on consumer decisions in using Grab-Food in Palembang by $25.0 \%$. Based
Based on the results of the $t$ test in the publicity factor

on the significant test results, the parameters of the direct marketing factor (X4) have a beta value of 0.250 with a t-test value of 2.121 greater than t-table 1.984 (t-count 2.121> t-table 1.984), with a significant probability level value of $\mathrm{t}($ Sig.) Of 0.037 smaller than Alpha 0.05 (Sig. $0.037<\alpha$ 0.05). This means that partially the direct marketing factor which includes direct interaction with potential Grab-Food consumers, in order to make presentations, answer questions and receive orders has a significant influence on consumer decisions by $25.0 \%$.

\section{CONCLUSION AND SUGGESTION}

\section{A. Conclusion}

Based on the results of previous studies and discussions, which have been carried out on the formulation of the problem, the following conclusions can be drawn:

1. Advertising has a positive and significant influence on consumer decisions to use Grab-Food in Palembang.

2. Sales Promotion has a positive and significant effect on consumer decisions in using Grab-Food in Palembang.

3. Publicity has a positive and significant effect on consumer decisions to use Grab-Food in Palembang.

4. Direct Marketing has a positive and significant effect on consumer decisions to use Grab-Food in Palembang.

5. Advertising, Sales Promotion, Publicity, Direct Marketing together have a positive and significant impact on Grab-Food consumer decisions in Palembang.

\section{B. Suggestions}

The following are various suggestions submitted by researchers based on the research results described above:

1. For Indonesian Grab Companies

a.Results from research can be seen that advertising has an influence on Grab-Food consumer decisions in Palembang. The results of the data show that advertising in general is good, but it still needs to be improved again such as making ads more attractive.

b.Results from research can be seen that sales promotions have an influence on Grab-Food consumer decisions in Palembang. The results of the data show that sales promotions are generally good, but still need to be improved in several things such as making promotional discounts to certain products so consumers are interested.

c.Results from this research can be seen that publicity has an influence on Grab-Food consumer decisions in Palembang. The results of the data show that publicity is generally good, but it still has to be increased by holding events and prizes that are even more interesting.

The results of this study can be seen that direct marketing has an influence on Grab-Food consumer decisions in Palembang. The results of the data show that direct marketing is generally good, but it still needs to be improved again in a number of things such as Grab-Food employees providing accurate and responsive information in dealing with consumers.

e.From the results of existing data indicate that advertising, sales promotion, publicity, and direct marketing have a positive and significant impact on consumer decisions in using Grab-Food in Palembang.

Published By:

Blue Eyes Intelligence Engineering

\& Sciences Publication

DOI:10.35940/ijmh.E0511.014520

Journal Website: www.ijmh.org

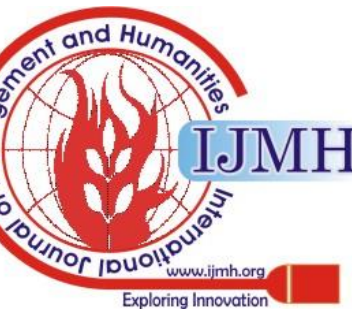


However, there are still several factors that have not been enough to influence consumer decisions, and there are still some answers from respondents who are still interested in using food delivery applications other than Grab Food. But it is still classified as being able to consider from the answer a little.

\section{For further researchers}

It is hoped that other researchers will be able to conduct further research on the influence of promotion mix factors (advertising, sales promotion, publicity, and direct marketing) on the decisions of consumers with a wider population, and add other relevant variables to further improve Grab-Food consumer decisions in the future.

\section{REFERENCES}

1. Arfandi, A.V (2019). "Pengaruh Kualitas Pelayanan Dan Promosi Terhadap Keputusan Konsumen Transportasi Online Di Kota Makassar".

2. Arifin \& Fachrodji (2015), "Pengaruh Bauran Promosi Terhadap Minat Beli Konsumen Ban Archilles di Jakarta Selatan”.

3. Arizqy, Sunarti \& Edriana (2016). "Pengaruh Bauran Promosi Terhadap Keputusan Berkunjung Dengan Citra Destinasi Sebagai Variabel Mediasi Survey pada Wisatawan Jawa Timur Park 1 Kota Batu".

4. Budi (2017). "Pengaruh Kualitas Produk, Harga, Dan Promosi Terhadap Keputusan Pembelian Dan Kepuasan Konsumen Teh Botol Sosro Di Semarang".

5. Chriswardana, B.D (2018). "Pengaruh Kualitas Pelayanan dan Promosi Penjualan Jasa Grabcar Terhadap Kepuasan Pelanggan (Studi Kasus Pada Wisatawan di Yogyakarta)".

6. Daniel, A.L. (2018). "Pengaruh Kualitas Pelayanan, Harga, Dan Promosi Terhadap Keputusan Pembelian Produk CKE Teknik Semarang".

7. Dewa, Agung (2015). "Pengaruh Bauran Promosi Terhadap Keputusan Pembelian OPPO SMARTPHONE".

8. Dewi, Donna, A.F. (2019). "Bauran Promosi Terhadap Pengambilan Keputusan Pemanfaatan Jasa Rawat Jalan Di Rsu Dr. H. Koesnadi Kabupaten Bondowoso".

9. Djatnika, T. (2012). Manajemen Pemasaran. Bandung: PT. Rosadakarya

10. Donny, Ernawan (2018). "Pengaruh Kualitas Produk Dan Promosi Terhadap Keputusan Pembelian Sabun Telepon Batang Serbaguna Pada Toko-Toko Retail Di Kecamatan Medan Marelan”.

11. Fatia, Maharani (2018). "Hubungan antara Terpaan Promosi Aplikasi My Blue Bird dan Citra Merek dengan Minat Konsumen untuk Menggunakan My Blue Bird sebagai Sarana Transportasi”.

12. Fajar, Helni (2018). "Pengaruh Bauran Promosi Terhadap Keputusan Pembelian Produk Secara Online Pada E-Commerce Shope".

13. Graham, John L. (2011). International Marketing. $15^{\text {th }}$ edition, McGraw-Hill. Jakarta: Salemba Empat

14. Irawan, F.W. (2015). Pemasaran, Prinsip, dan Kasus. Edisi ke dua. Yogyakarta: Liberty

15. Juliandi, A., \& Irfan. (2013). Metodologi Penelitian Kuantitatif Untuk Ilmu-ilmu Bisnis. Bandung: Citapustaka Media Perintis

16. Kotler, P., \& Kevin L. Keller. (2016). Marketing Management (15th ed.). Pearson Education.

17. Kotler, P. (2012). Manajemen Pemasaran. Jakarta: Salemba Empat

18. Kotler, P., \& Armstrong, G. (2012). Prinsip-prinsip Manajemen. Jakarta: Erlangga

19. Kotler, P., \& Kevin, L. K. (2009). Manajemen Pemasaran. Jakarta: Erlangga

20. Manurung, Tianur (2018). "Pengaruh Harga Dan Promosi Terhadap Keputusan Konsumen Pada PT. Grab Indonesia (GrabCar) Di Medan. Studi Kasus Pada Mahasiswa Yang Tinggal di Wilayah Medan Timur".

21. Michael, Christy (2016). "Pengaruh Strategi Bauran Promosi Regresi Produk Speedy Terhadap Perilaku linier Pembelian Konsumen pada PT. Berganda Telkom Indonesia, Kantor Daerah Telkom (Kandatel) Manado".

22. Muhammad, Arif \& Indira (2017). "Pengaruh Bauran Promosi Terhadap Keputusan Pembelian Produk OPPO SMARTPHONE di Kota Bandung)",
23. Nina, Abduannur (2017). "Pengaruh Bauran Promosi Terhadap Keputusan Konsumen Membeli Kosmetik Pond's di Kota Balik Papan".

24. Permatasari, N.B (2018). "Pengaruh citra merek dan promosi terhadap loyalitas konsumen Go-Jek di Kecamatan Wonocolo Surabaya".

25. Putri (2019). "Pengaruh Promosi Dan Kualitas Produk Terhadap Keputusan Pembelian Di PT. Smartfren Telecom Tbk Medan".

26. Sekaran, Uma. 2016. Research Methods for Business (Metodologi Penelitian untuk Bisnis). Edisi ke - 7. Jakarta : Bayu Media

27. Setiadi, N. (2010). Perilaku Konsumen : Perspektif Kontemporer Pada Motif, Tujuan dan Keinginan Konsumen. Jakarta: Kencana Prenada Media

28. Silitonga, Nurhasanah (2017). "Pengaruh Bauran Promosi Terhadap Keputusan Pembelian Pada PT. Asuransi Bhakti Bhayangkara Cabang Medan".

29. Sofia, Nazaruddin, (2019). "Pengaruh Strategi Promosi Terhadap Keputusan Pembelian Yang Dimediasi Oleh Minat Beli Pada Konsumen Restoran KFC Cabang Khatib Sulaiman Padang”.

30. Stanton, William J. 2013. Prinsip Pemasaran. Terjemahan Y Lamarto. Jakarta : Erlangga

31. Sugiyono. (2012). Metode Penelitian Pendidikan Pendekatan Kuantitatif, Kualitatif R\& D. Bandung: Alfabeta

32. Supranto, J., \& Limakrisna, N. (2011). Perilaku Konsumen (Vol. Vol Edisi 12). Jakarta: Mitra Wacana Media

33. Tiffani, Altje \& Jantje (2016). "Pengaruh Bauran Promosi Terhadap Kepuasan Konsumen pada Novotel Manado Golf Resort \& Convention Center".

34. Tjiptono, F. (2010). Strategi Pemasaran. Edisi ke Tiga. Yogyakarta: CV. Andi Off Set

35. Wahjono, S. I. (2010). Manajemen Pemasaran Bank. Yogyakarta: Graha Ilmu

36. William J. Stanton. (2013). Dasar-dasar Pemasaran. Edisi ke tujuh, Jakarta : Erlangga jilid ke-1 